\title{
ДО ПИТАНЬ ВИКОРИСТАННЯ ТА ІДЕНТИФІКАЦІЇ НЕОФІЦИНАЛЬНОЇ СИРОВИНИ - ЛИСТЯ ACORUS CALAMUS L.
}

\footnotetext{
Bcmуп. Acorus calamus L. - перспективна рослина для комплексного використання в медицині.

Мета дослідження - зіставити кількісний вміст ефрірної олії та їі компонентний склад у кореневищах і листі аїру, встановити перспективність використання листя, виявити морфолого-анатомічні діагностичні ознаки листя як нової сировини.

Методи дослідження. Методом хромато-мас-спектрометрії вивчали вміст та склад ефрірної олії, за допомогою загальноприйнятих методик аналізу - мікроскопічні ознаки сировини.

Результати й обговорення. Проведено порівняльний аналіз кількісного вмісту та якісного складу компонентів ефрірної олії аїру звичайного. Встановлені діагностичні морфологічні й анатомічні ознаки листя будуть використані при розробці нормативної документації-методів контролю якості на додаткову сировину.

Висновок. Результати досліджень вказують на перспективність подальшого фрармакогностичного вивчення листя аїру звичайного як додаткової і доступної лікарської сировини.

КЛЮчОВІ СЛОВА: аїр звичайний; листя; кореневища; морфолого-анатомічні ознаки.
}

ВСТУП. Однією з перспективних лікарських рослин є аїр звичайний (а. тростинний), лепеха звичайна (Acorus calamus L.) - багаторічна трав'яниста прибережно-водна рослина з родини аронникові, ароїдні (Araceae), підродини аїрні, аїрові (Acoroideae) [1]. В Європейській частині СНД росте по берегах повільно плинних річок, струмків, озер, ставків, у тихих затоках, балках. На території України основні масиви зосереджені в лісостеповихі поліських областях, у басейнах Дніпра, Сіверського Донця, Південного Бугу, Дністра. На жаль, немалі площі сконцентровані в зоні радіаційного забруднення, а прийнятні для заготівлі природні ресурси скорочуються чи перебувають під загрозою зникнення. Із 73 цінних лікарських рослин, занесених до Червоної книги України, відсутні сировинні експлуатаційні запаси 23 видів, серед них і аїр болотний. Зменшення заростей аїру пов'язане, з одного боку, з осушенням заболочених земель, виснаженням запасів унаслідок заготівлі кореневищ, якими рослина розмножується виключно вегетативним способом, 3 іншого - відсутністю координації між державними установами, відповідальними за невиснажливу експлуатацію () М. С. Яременко, Т. М. Гонтова, Л. М. Сіра, 2018. природних фріторесурсів (Міністерство аграрної політики, підрозділи Центральної спілки споживчих товариств України, Заготівельне акціонерне товариство “Ліктрави”, державний консорціум "Укрфітотерапія"), заготівельними організаціями та фрармацевтичною промисловістю. 3 метою есрективної охорони і захисту видового різноманіття, керованого і регульованого використання ресурсів харчових, лікарських, технічних та інших корисних рослин Міністерство екології та природних ресурсів України у 2000 р. започаткувало створення науково обґрунтованого Державного кадастру рослинного світу країни відповідно до Закону України “Про рослинний світ”. До пріоритетних видів лікарських рослин, які потребують першочергової уваги щодо збору й аналізу ресурсної кадастрової інфрормації, належить аїр звичайний [2-4].

Фармацевтична промисловість України, Німеччини, Франції, Індії та інших держав використовує кореневища аїру (Rhizomata calami) як офріційну сировину (Державна Фармакопея СРСР XI видання, Британська Фармакопея, Державна Фармакопея Республіки Білорусь, Німецький фрармацевтичний кодекс, Австрійська Фармакопея та Китайська Фармакопея). Препарати 
чинять різноманітну дію: дезінфрікувальну, протизапальну, ранозагоювальну, заспокійливу, сечо- і жовчогінну, спазмолітичну, тонізуючу, антигельмінтну. Їх використовують для лікування захворювань щитоподібної залози, рахіту, діатезу, геморою, жовтяниці, епілепсії, неврастенії, пневмонії, малярії, водянки, виразки шлунка, туберкульозу тощо. Рекомендовано жувати кореневище аїру при послабленні пам'яті, зору, для усунення печії, поганого запаху з рота, пристрасті до куріння. Порошком коренів присипають гнійні рани, виразки. Також кореневища використовують як прянощі в харчовій промисловості, при випіканні хліба, як приправу до риби, м'яса $[2,5,6]$.

Активним виробником препаратів з аїром $€$ Німеччина, декілька найменувань виробляють Польща, Франція, Індія, Болгарія. На даний час на території України в продажу наявні 24 вітчизняних лікарських препарати, до складу яких входить кореневище аїру. 3 них 6 - подрібнене кореневище в пачках і пакетах, 6 зборів, 10 рідких форм, таблетки ВІКАЛІН® і ВІКАїР $®$. Це свідчить про актуальність пошуку додаткових аналогічних сировинних джерел за рахунок відходів переробки кореневищ аїру $[2,6]$.

У неофріційній медицині, крім кореневища, застосовують листя, яке так само містить кумарини, фрлавоноїди, гіркий глікозид акорин і ефрірну олію, дубильні та інші біологічно активні речовини. Настій або відвари зборів з листям аїру, додані до мінеральних ванн, покращують психоемоційний стан хворих на радикуліт. Сік і настій листя використовують при захворюваннях дихальних шляхів, печінки, жовчовивідних шляхів і жовчного міхура, їх вживають при серцебитті, підвищеному кров'яному тиску, а також при виснаженні після перенесення іноекційної хвороби. Відваром листя миють голову для зміцнення волосся. Молоде запашне листя використовують замість салату, при лікувальному харчуванні хворих на цукровий діабет, для виготовлення варення. Сухе листя додають до борошна при випіканні хліба. Листя аїру вбиває комах-паразитів [2, 7-9].

Динаміка ресурсів аїру в лівобережному лісостепу та степу свідчить про те, що запаси обмежені, ресурси зменшуються, заготівля сировини підлягає суворому контролю. В останні роки помітно зростає відсоток дорогої імпортованої сировини для фрармацевтичної промисловості та аптечної мережі. Вирішенню національної проблеми десріциту вітчизняної сировини таких цінних лікарських рослин, як аїр болотний, сприятимуть: оптимізація використання наявних ресурсів; пошук резервів сировинних запасів в екологічно чистих регіонах України; впроваджен- ня комплексного застосування підземної і надземної частин цінної рослини, що дозволить зберегти природні зарослі, спростити заготівлю сировини і здешевити затрати. Також актуальним $€$ введення в культуру аїру болотного для забезпечення фрармацевтичної галузі екологічно чистою сировиною та збереження природних запасів $[3,4]$.

Мета дослідження - зіставити кількісний вміст ефрірної олії та її компонентний склад у кореневищах і листі аїру, встановити перспективність використання листя, виявити морфолого-анатомічні діагностичні ознаки листя як нової сировини.

МЕТОДИ ДОСЛІДЖЕННЯ. КіЛЬКіснИЙ ВМіст ефрірної олії та її компонентний склад визначали методом хромато-мас-спектрометрії з висушених зразків сировини, заготовленої на території Харківської області [8-10]. Мороролого-анатомічні дослідження свіжого листя і фріксованого в суміші спирт - гліцерин - вода (1:1:1) кореневища проводили за методиками гістологічного аналізу з використанням мікроскопів МБС 9, Item PB 2610 та фротокамери Samsung PL50 [7].

РЕЗУЛЬТАТИЙ ОБГОВОРЕННЯ. ЯК ПОКаЗаВ порівняльний аналіз літературних даних і результатів проведеного нами експерименту щодо кількісного вмісту та якісного складу компонентів ефрірної олії, вміст ефрірної олії в зразках кореневищ сягав 2,00 \%, а в листі - 1,74 \%. Методом хромато-мас-спектрометрії в кореневищах ідентифріковано такі групи сполук: сесквітерпеноїди $(37,8 \%)$, ароматичні речовини $(25,4 \%)$, монотерпеноїди (19,02 \%), жирні кислоти (4,62 \%), насичені вуглеводні (2,86 \%). Домінуючими компонентами були шиобунон (30,10\%), азарон $(19,12 \%)$, аромадендрен (10,43 \%) і $\beta$-каріофілен $(5,40 \%)$ [9]. Серед ідентифрікованих сполук у листі переважали сесквітерпеноїди (37,8 \%), ароматичні сполуки $(25,4$ \%) та монотерпеноїди (20,6 \%). Також були наявні такі групи сполук, як насичені (3,35 \%) та ненасичені (3,2 \%) жирні кислоти, дитерпени, тритерпени (2,9\%), насичені вуглеводні (1,4 \%). Серед індивідуальних сполук відмічено високий вміст азарону $(20,2 \%)$, $\beta$-каріофілену $(16,4 \%)$, гемакрену В $(9,7 \%)$, ठ-кадинену (7,9 \%) та ліналоолу (7,9 \%) [8]. Отримані дані свідчать про перспективність використання листя лепехи звичайної як додаткового виду сировини.

3 огляду на це, було проведено морфолого-анатомічні дослідження листя. Свіже листя (рис. 1) яскраво-зелене, м'ясисте, з характерним духмяним запахом і гірким присмаком. Розташоване зближено, двома рядами на горизонталь- 

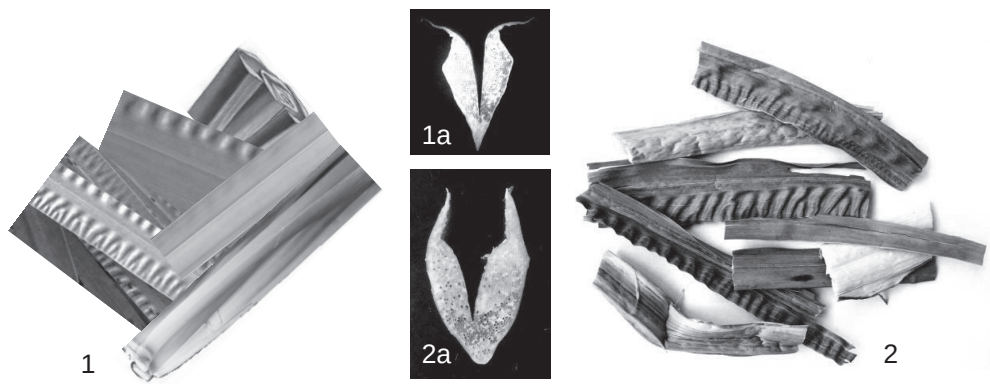

Рис. 1. Свіже соковите (1) та висушене (2) листя аїру зовні й у поперечному січенні (1a, 2a).

ному кореневищі, орієнтоване вертикально. За формою листки лінійно-мечоподібні, завширшки близько 3 см, завдовжки 60-120 см, поверхня гола, шкіряста, край цілісний, злегка гофрований. Відмітною ознакою листової пластинки $€$ те, що вона сплощена не у спинно-черевній площині, а з боків, має жолобок і гостре ребро - кіль. Це виглядає так, нібито пластинка була складена навпіл, а потім випрямлена. Біля основи пластинка світліша, в місці прикріплення розширена, утворює листкову піхву рожевого кольору. Піхви охоплюють усе або майже все коло кореневища і залишаються на ньому у вигляді плівчастих лусочок. Висушене листя (рис. 1) зморшкувате, гофроване по краю, поверхня бурувато-зелена, буро-коричнева, жовто-зелена, внутрішня частина біло-рожева, горбкувата.
Внаслідок того, що листя аїру сплощене 3 боків, уся поверхня листкової пластинки є лише морфрологічно нижньою, а структура цієї пластинки - амфістоматичною уніфраціальною (радіальною), тобто односторонньою. Структура плівчастих піхв біацифальна (двостороння), тобто хлоренхіма розташовується на абаксіальній стороні й відсутня на адаксіальній. У піхвах добре розвинена склеренхіма. Наростає листкова пластинка завдяки поділу інтеркалярної меристеми основи пластинки. Площа не збільшується за відсутності маргінального (крайового) зростання, як це відбувається у сплощених листках завдяки антиклінальному поділу крайової меристеми.

Мезофріл пластинки не однорідний (рис. 2). Субепідермальна хлоренхіма більш щільна,

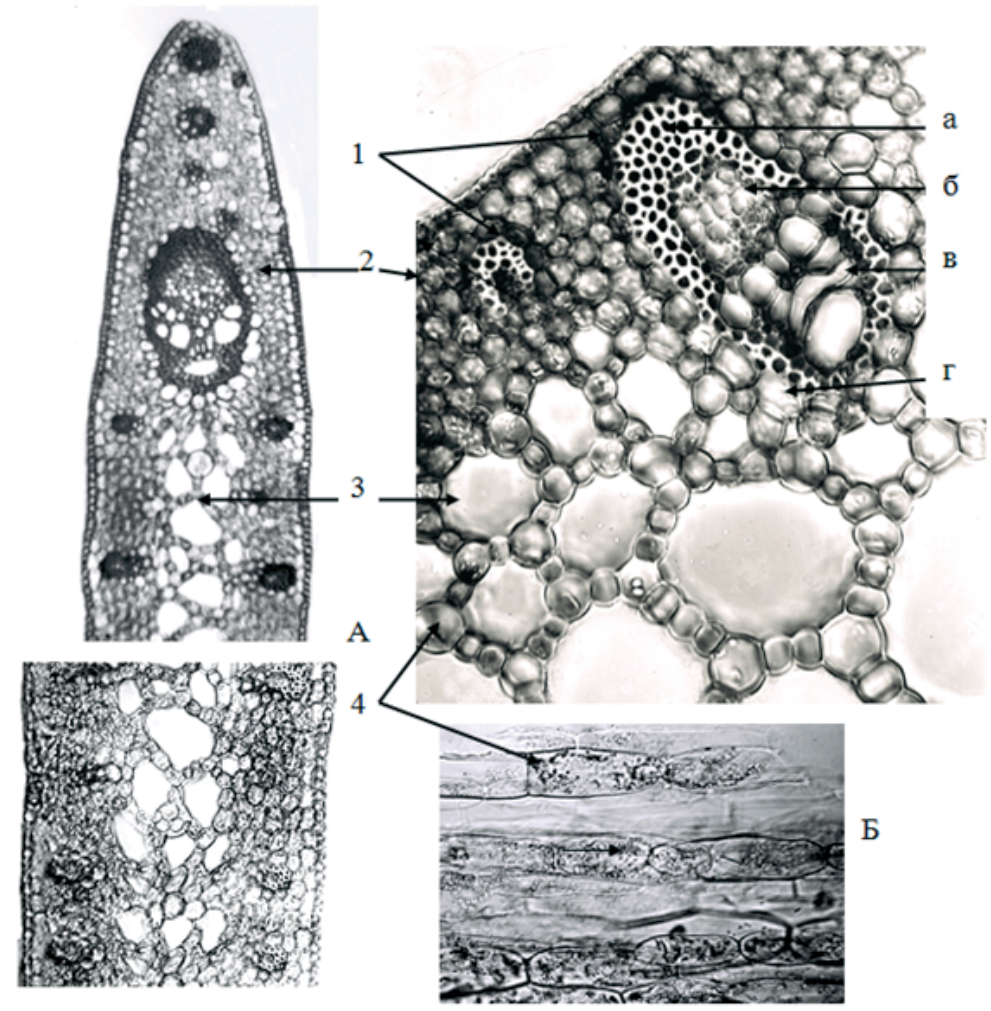

Рис. 2. Поперечні (А) та поздовжні (Б) зрізи листкової пластинки: 1 - маленькі й великі закриті колатеральні провідні пучки: а - склеренхіма, б - фрлоема, в - ксилема, г - паренхімна обкладка; 2 - хлоренхіма; 3 - аеренхіма; 4 - ідіобласти з ефірною олією. 
складається з 4-6 шарів, рівномірно розвинених по всьому колу пластинки. Клітини округлі, містять хлорофрілові й крохмальні зерна, поділяються і ростуть зі швидкістю, близькою до зростання епідерми, тому трохи відриваються одна від одної. Під хлоренхімою багато шарів клітин аеренхіми, які в поперечному січенні округлі, а у поздовжньому - видовжені (рис. 2). Вони припиняють поділ і зростання раніше хлоренхіми, відділяються, утворюючи великі міжклітинники. Серед клітин аеренхіми рівномірно розподілені більші за розміром й округлі клітини-ідіобласти 3 блискучою кремуватою ефрірною олією. Раніше встановлено, а нами підтверджено, що кількість ідіобластів і вміст есрірної олії взаємозумовлені й залежать від срази розвитку та дії чинників навколишнього середовища. У листках найбільшу кількість ідіобластів та ефірної олії виявляють у фазу цвітіння, активної асиміляції і цитохімічних перетворень.

Провідна система листків представлена жилками, які йдуть уздовж листкової пластинки, зближуються в її верхівці, на якій досить часто міститься гідатода. Провідні пучки відрізняються розміром, за складом можуть бути повними, неповними і простими. Пучки зазвичай не примикають до клітин мезофрілу, але оточені обкладкою 3 паренхіми, яка забезпечує контакт між основними тканинами та провідними елемента- ми ксилеми і фрлоеми. Більшість пучків супроводжує склеренхіму і дрібні кристалики кальцій оксалату (рис. 3). Великі колатеральні пучки чергуються з дрібними пучечками, що проходять під палісадною паренхімою, у верхньому шарі аеренхіми (рис. 2). У великих пучках є судини, а у фрлоемі - ситоподібні трубки. У дрібних пучках судини змінюються трахеїдами, а ситоподібні трубки фрлоеми - паренхімними клітинами. Прості пучки є закінченнями жилок листка і найчастіше складаються з 1-2 трахеїд.

На зрізах пластинки в ділянці кіля серед провідних пучків хлоренхіми виділяються більший за розміром колатеральний судинно-волокнистий пучок прокамбіального походження і 3-4 (іноді 6-8) дрібних пучечків. Ксилема орієнтована до абаксіальної поверхні, обкладка пучків паренхімна.

Базисні клітини епідерми листкової пластинки (рис. 3) видовжені в результаті того, що рано припиняють поділ, але поступово розтягуються. Бічні оболонки клітин тонкі, зовнішні - вкриті тонким шаром кутикули. Деякі коротші за розміром клітини містять дрібні друзи (рис. 3). Продихи (рис. 3) парацитні або тетрацитні, знаходяться на одному рівні з епідермальними клітинами, розміщуються рядами вздовж осі листка між жилками, які супроводжуються кристалами кальцій оксалату.
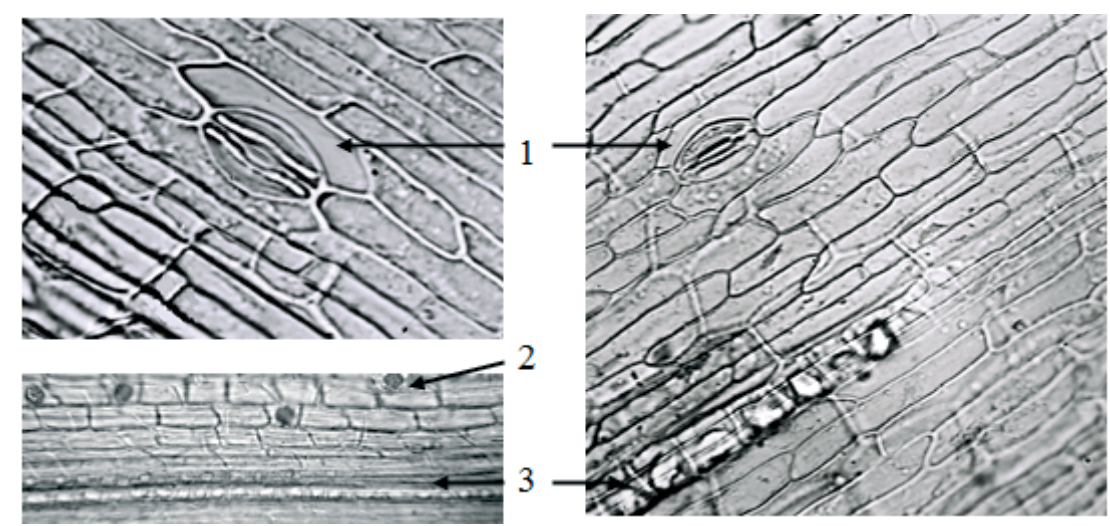

Рис. 3. Мікропрепарати листкової пластинки аїру болотного з поверхні: 1 - продихи; 2 - друзи; 3 - кристали кальцій оксалату вздовж жилок.

ВИСНОВОК. Результати хімічних та мікроскопічних досліджень $€$ підставою для подальшого фрармакогностичного вивчення листя аїру болотного як додаткової і доступної лікар- ської сировини. Отримані дані будуть враховані при розробці методів контролю якості на лікарську рослинну сировину та її стандартизації. 


\section{СПИСОК ЛІТЕРАТУРИ}

1. Определитель высших растений Украины / [Д. Н. Доброчаева, М. И. Котов, Ю. Н. Прокудин и др.]. К. : Наукова думка, 1987. - С. 468.

2. Зузук Б. М. Аир тростниковый (аналитический обзор) / Б. М. Зузук, Р. В. Куцик // Провизор. - 2002. № 8. - C. 34-39.

3. Мінарченко В. М. Ресурси лікарських рослин України: диференціація, динаміка, стратегія оптимізації використання і збереження : авторефр. дис. на здобуття наук. ступеня д-ра біол. наук / В. М. Мінарченко. - К., 2012. - 37 с.

4. Національна доповідь про стан навколишнього природного середовища в Україні за 1998 рік [Електронний ресурс]. - Режим доступу : http://nature.org. ua/nr98/ukrvers/contr/index.htm.

5. Гурьев А. М. Фармакогностическое исследование аира болотного и перспективы создания на его основе новых лекарственных средств : авторефр. дис. на соискание учен. степени канд. фрармац. наук А. М. Гурьев [Сиб. гос. мед. ун-т М-ва здравоохранения Рос. Федерации]. - Томск : Б.и., 2004. - 20 с.
6. Державний реєстр лікарських засобів України [Електронний ресурс]. - Режим доступу : http://www. drlz.com.ual.

7. Атлас по анатомии растений (растительная клетка, ткани, органы) : учеб. пособ. для студ. высш. учеб. заведений / А. Г. Сербин, Л. С. Картмазова, В. П. Руденко, Т. Н. Гонтовая. -Х. : Колорит, 2006. - 86 с.

8. Гонтова Т. М. Дослідження компонентного складу ефірної олії листя лепехи звичайної / Т. М. Гонтова, О. Ю. Таллер // Зб. наук. праць співроб. НМАПО ім. П. Л. Шупика. -К., 2014. - Вип. 23 (4). - С. 254-259.

9. Гонтова Т. М. Хромато-мас-спектрометричне вивчення летких сполук кореневищ лепехи звичайної / Т. М. Гонтова, М. С. Яременко // Зб. наук. праць співроб. НМАПО ім. П. Л. Шупика. -К., 2015. - Вип. 24 (5). C. $77-82$.

10. Державна Фармакопея України : в 3 т. / Державне підприємство "Український науковий фрармакопейний центр якості лікарських засобів". - 2-ге вид. Харків : Державне підприємство "Український науковий фрармакопейний центр якості лікарських засобів", 2014. - T. 1. - C. 379-381.

7. Serbin, A.G., Kartmazova, L.S., Rudenko, V.P., \& Gontovaya, T.N. (2006). Atlas po anatomii rasteniy (rastitelnaya kletka, tkani, organy) [Atlas on plant anatomy (plant cell, tissues, organs)]. Kharkiv: Kolorit [in Ukraine].

8. Hontova, T.M., \& Taller, O.lu. (2014). Doslidzhennia komponentnoho skladu efirnoi olii lystia lepekhy zvychainoi [The research component composition of essential oil leaves Acorus Calamus]. Zbirnyk naukovykh prats spivrobitnykiv NMAPO im. P.L. Shupyka-Collection of Scientific Works of Staff Member of P.L. Shupyk NMAPE, 23 (4), 254-259 [in Ukraine].

9. Hontova, T.M., \& Yaremenko, M.S (2015). Khromato-mas-spektrometrychne vyvchennia letkykh spoluk korenevyshch lepekhy zvychainoi [Chromatographymass spectrometry study of volatile compounds rhizomes Acorus Calamus]. Zbirnyk naukovykh prats spivrobitnykiv NMAPO im. P.L. Shupyka - Collection of Scientific Works of Staff Member of P.L. Shupyk NMAPE, 24 (5), 77-82 [in Ukraine].

10. Ukrainian Scientific Pharmacopoeial Center for Quality of Medicines (2014). Vyznachennia vmistu efirnykh olii $v$ likarskii roslynnii syrovyni [Determination of the content of essential oils in medicinal plant material]. Derzhavna Farmakopeia Ukrainy - State Pharmacopoeia of Ukraine (2d ed., vol.1, p. 379-381) - Kharkiv: Ukrainian Scientific Pharmacopoeial Center for Quality of Medicines [in Ukraine]. 


\section{К ВОПРОСАМ ИСПОЛЬЗОВАНИЯ И ИДЕНТИФИКАЦИИ НЕОФИЦИНАЛЬНОГО СЫРЬЯ - ЛИСТЬЕВ ACORUS CALAMUS L.}

Резюме цине.

Вступление. Acorus calamus L. - перспективное растение для комплексного использования в меди-

Цель исследования - сопоставить количественное содержание эфирного масла и его компонентный состав в корневищах и листьях аира, установить перспективность использования листьев, выявить морфролого-анатомические диагностические признаки листьев как нового сырья.

Методы исследования. Методом хромато-масс-спектрометрии изучали содержание и состав эфрирного масла, с помощью общепринятых методик анализа - микроскопические признаки сырья.

Результаты и обсуждение. Проведен сравнительный анализ количественного содержания и качественного состава компонентов эфирного масла аира обыкновенного. Установленные диагностические морфологические и анатомические признаки листьев будут использованы при разработке нормативной документации - методов контроля качества на дополнительное сырье.

Вывод. Результаты исследований указывают на перспективность дальнейшего фрармакогностического изучения листьев аира обыкновенного как дополнительного и доступного лекарственного сырья.

КЛЮЧЕВЫЕ СЛОВА: аир обыкновенный; листья; корневища; морфолого-анатомические признаки.

M. S. Yaremenko, T. M. Gontova, L. M. Sira NATIONAL UNIVERSITY OF PHARMACY, KHARKIV

\section{ABOUT USE AND IDENTIFICATION OF NOT OFFICINALIS RAW MATERIALS - ACORUS CALAMUS L. LEAVES}

\section{Summary}

Introduction. Acorus calamus L. is a perspective medical plant for complex use in medicine.

The aim of the study - comparison of the quantitative content of essential oil and its component composition in the rhizomes and leaves of calamus, establishing the prospects for using leaves, revealing the morphological and anatomical diagnostic features of leaves as a new raw material.

Research Methods. The content and composition of the essential oil were studied using the CMS method, the microscopic characteristics of the raw material - generally accepted analytical methods.

Results and Discussion. A comparative analysis of the quantitative content and qualitative composition of the essential oil components of the acorus calamus were conducted. The established diagnostic morphological and anatomical signs of the leaves will be used in the development of normative documentation - quality control methods (QCM) for additional raw materials.

Conclusion. The results of the studies indicate the prospect of further pharmacognostic study of the leaves of the calamus as an additional and accessible raw material.

KEY WORDS: acorus calamus; leaves; rhizomes; morphological and anatomical signs.

Отримано 28.12.17

Адреса для листування: М. С. Яременко, Національний фрармацевтичний університет, вул. Валентинівська, 4, Харків, 61168, Україна, e-mail: caecys@gmail.com. 